\title{
Pain outcomes in patients with bone metastases from advanced cancer: assessment and management with bone-targeting agents
}

\author{
Donald L. Patrick • Charles S. Cleeland • \\ Roger von Moos • Lesley Fallowfield • Rachel Wei • \\ Katarina Öhrling • Yi Qian
}

Received: 6 August 2014 / Accepted: 14 November 2014 / Published online: 23 December 2014

(C) Springer-Verlag Berlin Heidelberg 2014

\begin{abstract}
Bone metastases in advanced cancer frequently cause painful complications that impair patient physical activity and negatively affect quality of life. Pain is often underreported and poorly managed in these patients. The most commonly used pain assessment instruments are visual analogue scales, a single-item measure, and the Brief Pain Inventory Questionnaire-Short Form. The World Health Organization analgesic ladder and the Analgesic Quantification Algorithm are used to evaluate analgesic use. Bone-targeting agents, such as denosumab or bisphosphonates, prevent skeletal complications (i.e., radiation to bone, pathologic fractures, surgery to bone, and spinal cord compression) and can also improve pain outcomes in patients with metastatic bone disease. We have reviewed pain outcomes and analgesic use and reported pain data from an integrated analysis of randomized controlled studies of denosumab versus the bisphosphonate zoledronic acid (ZA) in patients with bone metastases from advanced solid tumors. Intravenous bisphosphonates
\end{abstract}

D. L. Patrick $(\bowtie)$

Department of Health Services, University of Washington, Box 359455, 4333 Brooklyn Ave NE, Rm 14-101, Seattle,

WA 98195-9455, USA

e-mail: donald@uw.edu

C. S. Cleeland

Department of Symptom Research, University of Texas MD

Anderson Cancer Center, Houston, TX, USA

R. von Moos

Department of Oncology and Hematology, Cantonal Hospital

Graubünden, Chur, Switzerland

L. Fallowfield

Sussex Health Outcomes Research and Education in Cancer

(SHORE-C), University of Sussex, Falmer, UK

R. Wei $\cdot$ K. Öhrling $•$ Y. Qian

Amgen Inc., Thousand Oaks, CA, USA improved pain outcomes in patients with bone metastases from solid tumors. Compared with ZA, denosumab further prevented pain worsening and delayed the need for treatment with strong opioids. In patients with no or mild pain at baseline, denosumab reduced the risk of increasing pain severity and delayed pain worsening along with the time to increased pain interference compared with ZA, suggesting that use of denosumab (with appropriate calcium and vitamin D supplementation) before patients develop bone pain may improve outcomes. These data also support the use of validated pain assessments to optimize treatment and reduce the burden of pain associated with metastatic bone disease.

Keywords Pain $\cdot$ Bone metastases $\cdot$ Cancer .

Bone-targeting agents $\cdot$ Denosumab $\cdot$ Zoledronic acid .

Bisphosphonates $\cdot$ Radiotherapy $\cdot$ Analgesia $\cdot$ Quality of life

\section{Introduction}

Bone metastases are common in patients with advanced cancer, arising in $70 \%$ to $80 \%$ of patients with breast or prostate cancer and $30 \%$ to $40 \%$ of patients with lung cancer or other solid tumors [1]. Skeletal-related events (SREs), such as radiation to bone, pathologic fractures, surgery to bone, and spinal cord compression, are frequent pain-producing complications associated with bone metastases and can impair physical activity and mobility, reduce social activity and ability to carry out daily tasks, decrease independence, and lower quality of life [1-5]. Furthermore, depression and anxiety are increased following SREs [6]. Without systematic monitoring of pain using validated patient-reported outcome assessments, patients' pain is often underreported and inadequately managed [7]. Indeed, undertreatment of bone pain is common, in up to $55 \%$ of patients with advanced cancer, which further adds to the burden of disease $[8,9]$. 
The World Health Organization (WHO) ladder, issued in 1996, is a three-step framework for the management of cancer-related pain, in which the choice of drugs used to manage pain on the so-called analgesic ladder is determined by pain severity [10]. More recently, several organizations have issued comprehensive guidelines for management of cancer pain, encompassing topics such as pain assessment; treatment of mild, moderate to severe, and breakthrough pain; opioid switching, scheduling, and titration of opioid analgesics; and management of adverse events associated with opioids [11-13]. In addition to analgesics, these guidelines also emphasize the important role of bone-targeting therapy and radiotherapy in the management of bone pain due to bone metastases (Fig. 1) [11, 14].

Bone-targeting agents such as bisphosphonates and denosumab have been shown to reduce skeletal complications and the worsening of pain associated with bone metastases in patients with advanced solid tumors [15-23] and are recommended for patients with or without pain due to bone metastases from solid tumors [11]. These different bone-targeting agents vary in their efficacy for prevention of SREs and pain. There are also advantages and disadvantages with specific bone-targeting agents based on their different modes of action, routes of administration (i.e., oral, intravenous, or subcutaneous), and toxicity profiles that can contribute to the overall burden of disease [24].
The objective of this article is to provide an overview of pain data reported in clinical trials of bone-targeting agents in patients with advanced cancer and bone metastases. In addition, we present new results on pain outcomes from an integrated analysis of patients who received either the nitrogencontaining bisphosphonate zoledronic acid (ZA) or denosumab, a fully human monoclonal antibody that inhibits RANKL, for prevention of SREs in breast cancer, prostate cancer, and other solid tumors.

\section{Pain and analgesic use assessments in the clinical trial setting}

Pain assessments

Effective pain assessment, preferably using at least two different items to evaluate the clinical importance of pain worsening or improvement [25], is a critical component for proper management of patients with bone metastases. A variety of strategies discussed in this review have been used in clinical trials to assess pain in patients with cancer (Table 1). A systematic review identified 49 studies that included patientreported pain outcomes to assess bisphosphonate therapy in patients with bone metastases. The most frequent approaches to assess pain, used in 24 of the publications, were single-item
Fig. 1 Algorithm for the management of pain due to bone metastases. Reproduced with permission from Ripamonti CI, Santini D, Maranzano E, et al. Management of cancer pain: ESMO Clinical Practice Guidelines. Ann Oncol 2012;23(suppl 7):vii139-54 $S R E=$ skeletal-related event

\section{Treatment of pain due to bone metastases}

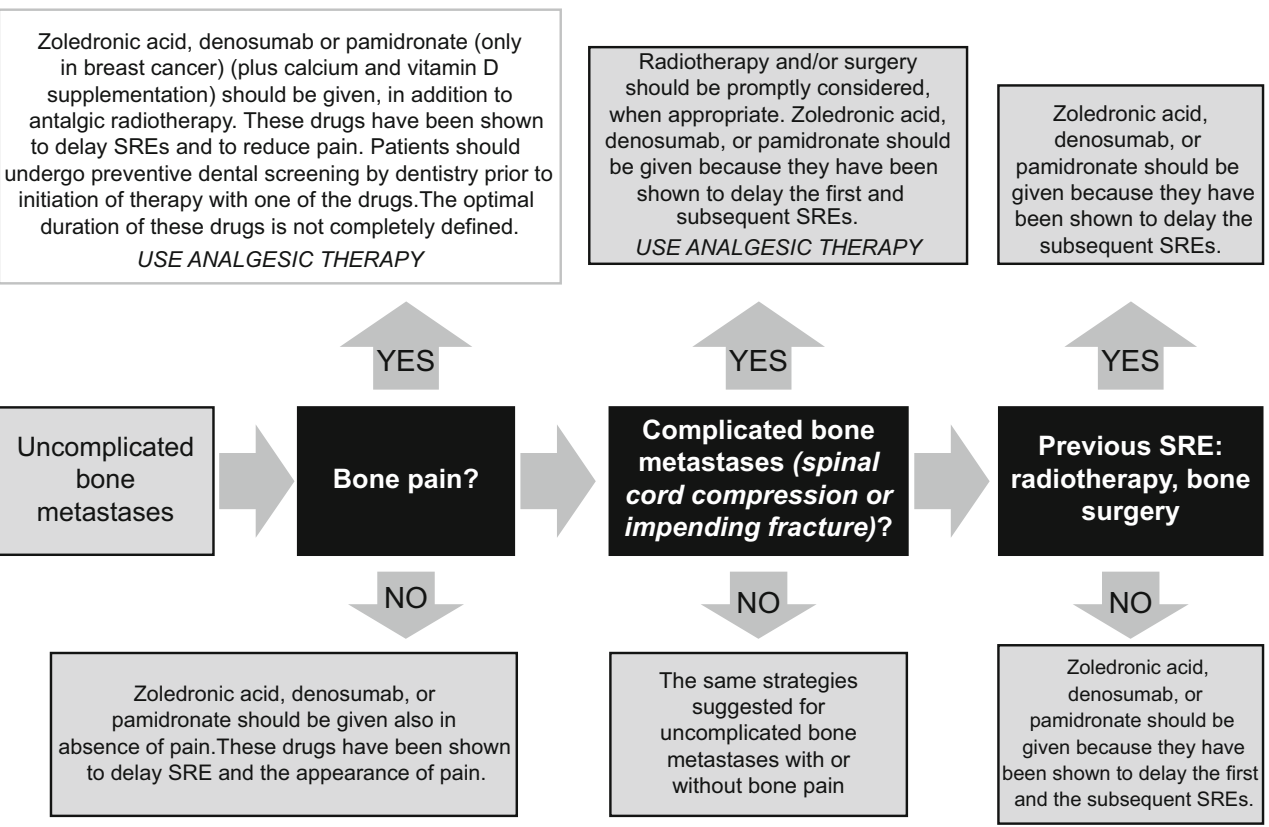


Table 1 Pain and analgesic use assessments in the clinical trial setting

\begin{tabular}{|c|c|c|}
\hline Pain assessment tool & Description of tool & Measures derived from the main tool \\
\hline WHO pain ladder [10] & $\begin{array}{l}\text { Four-point scale } \\
0 . \text { No analgesic } \\
\text { 1. Nonopioid } \\
\text { 2. Weak opioid } \\
\text { 3. Strong opioid }\end{array}$ & \\
\hline AQA $[26,27]$ & $\begin{array}{l}\text { Eight-point scale } \\
0 . \text { No analgesic } \\
\text { 1. Nonopioid } \\
\text { 2. Weak opioid } \\
\text { 3. } \leq 75 \mathrm{mg} \text { OME per day } \\
\text { 4. }>75-150 \mathrm{mg} \text { OME per day } \\
\text { 5. }>150-300 \mathrm{mg} \text { OME per day } \\
\text { 6. }>300-600 \mathrm{mg} \text { OME per day } \\
\text { 7. }>600 \mathrm{mg} \text { OME per day }\end{array}$ & $\begin{array}{l}\text { Strong opioid use } \\
\text { - Proportion of patients who progress to strong opioid use (category }>2 \text { ) } \\
\text { - Proportion of patients using strong opioids, by dose } \\
\text { Change in analgesic use } \\
\text { - Time to strong opioid use (category }>4 \text { ) } \\
\text { - Proportion of patients who progress to strong opioid use }\end{array}$ \\
\hline BPI-SF [26, 28-30] & $\begin{array}{l}\text { 15-point questionnaire on pain severity } \\
\text { and pain interference (scale, } 0-10) \\
\text { 0: No pain } \\
\text { 1-4: Mild pain } \\
\text { 5-6: Moderate pain } \\
\text { 7-10: Severe pain } \\
\text { 0: No interference } \\
\text { 10: Complete interference } \\
\text { Parameters } \\
\text { - Pain location(s) } \\
\text { - Worst pain } \\
\text { - Least pain } \\
\text { - Average pain } \\
\text { - Current pain } \\
\text { - Pain treatments and medications } \\
\text { - Relief of pain from treatments } \\
\text { - Pain interference with } \\
\text { - Activity } \\
\text { - Mood } \\
\text { - Interpersonal relationships } \\
\text { - Sleep } \\
\text { - Enjoyment of life }\end{array}$ & $\begin{array}{l}\text { - A two-point change is the minimally important difference } \\
\text { Change in pain severity } \\
\text { - Time to } \geq 2 \text {-point change from baseline } \\
\text { - Proportion of patients with } \geq 2 \text {-point change } \\
\text { Delay in pain progression } \\
\text { - Time to moderate to severe pain (score, }>4 \text { ) } \\
\text { - Proportion of patients who progressed to moderate to severe pain } \\
\text { Change in pain interference } \\
\text { - Time to } \geq 2 \text {-point change from baseline } \\
\text { Progression of mean pain intensity } \\
\text { - Increase of } \geq 30 \% \text { from baseline } \\
\text { Progression of worst pain intensity } \\
\text { - Increase of } \geq 30 \% \text { from baseline } \\
\text { Progression of pain interference with activity } \\
\text { - Increase of } \geq 50 \% \text { from baseline }\end{array}$ \\
\hline
\end{tabular}

$A Q A$ Analgesic Quantification Algorithm, BPI-SF Brief Pain Inventory-Short Form, OME oral morphine equivalent, WHO World Health Organization

instruments such as visual analogue scale (VAS), numeric rating scale, and verbal rating scale [31]. These instruments have the advantage of being simple and quick to administer. However, a single-item measure does not provide a full picture of a patient's pain experience. The most frequently used standardized instrument identified in the systematic review was the Brief Pain Inventory (BPI) questionnaire, which was used, at least in part, in 13 studies. It was also the only multiitem scale instrument used in more than a single study. The BPI is a modified version of the Wisconsin Brief Pain Questionnaire that measures both pain and its functional impact. It was developed for patients with cancer and includes questions regarding pain location; pain relief; functional interference due to pain; and worst, least, and average severity on a ten-point scale. 
Several measures have been derived from the BPI-Short Form (BPI-SF) results to provide a clearer picture of patient improvement or deterioration trends. A key component of these measures is that a two-point change on the BPI scale can be regarded as a minimally important difference when considering a change in a patient's pain experience [28]. The minimally important difference was established based on both anchor- and distribution-based methods. Patients have been measured for pain improvement ( $\geq 2$-point decrease) or worsening ( $\geq 2$-point increase); progression from no or mild pain (score of $\leq 4$ ) at baseline to moderate or severe pain (score $>4$ ); and pain interference, which can be further broken down into interference with normal daily activity, affect (i.e., interpersonal relationships, enjoyment of life, and mood), and overall pain interference $[26,32,33]$. These measures can be calculated based on either time to change or the proportion of patients who experience a change. Pain progression has also been defined as an increase of $\geq 30 \%$ in mean or worst pain intensity scores from baseline, but these criteria may be less clinically relevant than the two-point minimum change in study populations with no or minimal pain at baseline [29].

\section{Analgesic use assessments}

In studies in which pain is assessed, concurrent analgesic use is an important consideration, although consistent use of these measures in clinical trials may be problematic. Conventionally, this measurement has been divided into three broad categories based on the WHO analgesic ladder [10], which can be used as a surrogate measure of pain severity. The Analgesic Quantification Algorithm (AQA) is an expanded version of the WHO ladder that is divided into eight points: no analgesic, nonopioid analgesics, weak opioids, and strong opioids ( $\leq 75 \mathrm{mg},>75-150 \mathrm{mg},>150-300 \mathrm{mg},>300-600 \mathrm{mg}$, and $>600 \mathrm{mg}$ oral morphine equivalents per day) [27]. Unlike the stratification in the WHO ladder, which has a ceiling effect and tends to cluster patients at the strong opioid step, the stratification of strong opioids into five levels in the AQA allows for a greater ability to observe patient progression in analgesic use [27]. Results from the AQA can be used to observe trends in analgesic use, both in the proportion of patients who change analgesic use and in the time to change [26].

\section{Pain outcomes in clinical studies of bisphosphonates in patients with bone metastases from solid tumors}

The effects of bisphosphonates, such as pamidronate, clodronate, and ibandronate, on pain outcomes in patients with bone metastases from advanced cancer were investigated before the development of denosumab. In a randomized double-blind study enrolling patients with bone metastases from breast cancer $(N=380)$, treatment with intravenous pamidronate was associated with less increased pain overall $(P=0.046)$ and less increased pain in patients with pain at baseline ( $P=0.03)$ compared with placebo [34]. These improvements were maintained for 2 years in an extension study [35]. Among patients with no or mild pain at baseline, treatment with pamidronate decreased the incidence of $\geq 1$-point pain increase ( $28 \%$ vs. $37 \%)$ and delayed the time to increased pain $(P=0.043)$ compared with placebo; similar results were observed among patients with pain at baseline [35]. Increased analgesic use was also less frequent among patients who received pamidronate compared with placebo ( $26 \%$ vs. $40 \% ; P=0.011$ ). In a 2 -year phase $1 / 2$ trial assessing intravenous pamidronate among patients with bone metastases who were also receiving hormone therapy for breast cancer, treatment with pamidronate improved pain scores during the first year of treatment $(P=0.002$ at cycle 12$)$ and reduced analgesic use compared with placebo [36]. In a phase 3 study assessing intravenous ibandronate in patients with bone metastases from breast cancer $(N=466)$, treatment with ibandronate improved patient quality of life and bone pain over time and decreased the need for analgesic use compared with placebo [37, 38]. In two double-blind studies, treatment with oral ibandronate $50 \mathrm{mg}$ once daily for up to 96 weeks in 564 patients with metastatic bone disease from breast cancer significantly reduced pain scores from baseline, reduced analgesic use, and resulted in fewer patients with moderate to intolerable pain compared with placebo [39]. A small openlabel study in 13 patients with breast cancer reported decreased bone pain and analgesic use at 2 weeks following a loading dose of intravenous ibandronate $(6 \mathrm{mg}$ /day for three consecutive days) [40]. In a randomized double-blind study $(N=209)$, treatment with clodronate did not increase the rate of palliative pain response versus mitoxantrone in patients with bone metastases and hormone-refractory prostate cancer [41].

More recently, the bisphosphonate ZA has been shown to improve pain and quality of life in patients with bone metastases from solid tumors, including breast, prostate, and lung cancers $[19,20,22,42]$. In a placebo-controlled phase 3 study assessing the efficacy and safety of ZA in men with bone metastases from hormone-refractory prostate cancer, the increase in mean pain score from baseline per the BPI at study month 15 was smaller in patients treated with ZA compared with placebo ( 0.58 vs. $0.88 ; P=0.134)$ [19]. No significant difference in analgesic use between treatment groups was reported [19]. Using a longitudinal approach to assess the proportions of patients with pain relief ( $\geq 2$ points per the BPI) at various time points, Weinfurt et al. reported that, in the 138 patients (ZA, $n=76$; placebo, $n=62$ ) who completed the 60-week BPI assessment, treatment with ZA improved pain responses at all time points compared with placebo (overall mean rate, $33 \%$ vs. $25 \% ; P=0.036$ ) [43]. A phase $3 \mathrm{~b}$ openlabel crossover study demonstrated that, in patients with bone metastases from breast cancer, treatment with ZA reduced 
worst pain $(P=0.008)$ and interference with activity $(P=0.012)$, walking ability $(P<0.001)$, enjoyment of life $(P=0.005)$, and sleep $(P=0.015)$ relative to baseline [44]. Similarly, in a phase 3 head-to-head trial to assess the efficacy and safety of ZA versus pamidronate in patients with bone metastases from breast cancer or multiple myeloma and osteolytic bone lesions, the BPI composite pain scores were reduced equivalently in the ZA and pamidronate treatment arms [45].

In an open-label study $(N=312)$, among 237 patients with recent bone metastases from breast cancer evaluated for pain, 138 (58 \%) experienced a decrease from baseline in the BPI composite pain score at the end of treatment, and among 157 patients using analgesics at baseline, $83 \%$ reported decreased use or no change in use following treatment with ZA [46]. An open-label multicenter study investigating the effect of ZA on bone pain and analgesic treatment for 1 year in 604 patients with bone metastases from predominantly breast, urogenital, and lung tumors showed that pain assessed using the mean VAS decreased from baseline during the course of the study from 37.1 to $23.2 \mathrm{~mm}(P<0.0001)$ [47]. Treatment with ZA also decreased the need for analgesics per the mean VAS score $(P<0.0001) ; 24 \%$ of patients with a baseline analgesic score of 4 no longer required the use of opioids at the end of the study [47].

\section{Pain outcomes in clinical studies comparing zoledronic acid with denosumab in patients with bone metastases from solid tumors}

The approval of denosumab, a fully human monoclonal antibody, as a bone-targeting therapy for the prevention of SREs was based on the results of three randomized, double-blind, phase 3 studies that enrolled 5,723 patients with bone metastases from breast cancer, prostate cancer, or advanced solid tumors (excluding breast or prostate) or multiple myeloma [15-17]. Analyses of these studies have shown improvements in patient-reported pain outcomes associated with subcutaneous denosumab $120 \mathrm{mg}$ compared with intravenous ZA $4 \mathrm{mg}$ monthly (Table 2). Among patients with bone metastases from breast cancer in a randomized, double-blind study, treatment with denosumab $(n=1,026)$ was associated with a lower incidence of pain worsening by $\geq 2$ points per BPI-SF, delayed progression from no or mild pain to moderate or severe pain (9.7 vs. 5.8 months; $P=0.0024$ ), improved pain interference, and delayed time to increased pain interference by $\geq 2$ points ( 16.0 vs. 14.9 months; $P=0.09$ ) compared with ZA $(n=1,020)$ [26]. Data from this study also showed that, independent of baseline pain levels, $10 \%$ more patients who received denosumab than ZA experienced improvement in healthrelated quality of life [48]. Similarly, data from a randomized, double-blind trial in patients with bone metastases from castration-resistant prostate cancer who received denosumab $(n=950)$ or ZA $(n=951)$ [15] showed fewer patients treated with denosumab reported pain worsening, progression from no or mild pain to moderate or severe pain, pain interference, or the need for strong opioids per the AQA [32, 33]. Likewise, data from a randomized, double-blind study in patients with bone metastases from other solid tumors [17] showed that treatment with denosumab $(n=800)$ versus ZA $(n=797)$ delayed time to development of moderate or severe pain (4.7 vs. 3.7 months; $P=0.05$ ), delayed pain worsening (5.6 vs. 4.6 months; $P=0.016$ ) and worsening of pain interference (8.2 vs. 4.8 months; $P=0.021$ ), and reduced the need for strong opioids [50]. Because the study designs of the double-blind phase 3 studies were identical, an integrated analysis of pain outcomes per BPI and analgesic use per the AQA could be performed [51]. Overall, treatment with denosumab compared with ZA was associated with an $8 \%$ lower risk of increased pain severity $(P=0.020)$ and reduced use of strong opioids ( $-13.4 \%$ difference). Among patients with no or mild pain at baseline, denosumab delayed the increase in worst pain (4.6 vs. 3.1 months), reduced the risk of increased severity by $13 \%(P=0.002)$, delayed the onset of moderate to severe pain ( 6.5 vs. 4.7 months), and reduced the risk of progression to severe pain by $17 \%(P<0.001)$ compared with ZA. Treatment with denosumab also delayed $\mathrm{a} \geq 2$-point increase in pain interference overall (11.1 vs. 9.3 months; $P=0.010$ ), as well as pain interference with affect ( 8.4 vs. 7.5 months; $P=0.027)$ and with activity ( 8.3 vs. 7.4 months; $P=0.017$ ) compared with ZA. In patients with no or mild pain at baseline, denosumab delayed the time to increase in pain interference overall (10.3 vs. 7.7 months; $P<0.001$ ), as well as pain interference with affect (9.2 vs. 7.4 months; $P=0.003$ ) and with activity (7.6 vs. 6.0 months; $P=0.002$ ).

New results from the integrated analysis of pain outcomes with denosumab versus ZA in phase 3 trials are presented in Table 3. Across all three studies, baseline BPI-SF pain scores (worst pain and pain interference, including pain interference subsets of activity and affect) were significantly higher in patients who had a history of SREs $(P<0.0001$ for all $)$ and tended to be higher for patients who had elevated baseline bone turnover markers urinary $\mathrm{N}$-telopeptide or baseline bone-specific alkaline phosphatase. Among all patients with available patient-reported outcome data, treatment with either denosumab or ZA was associated with improvement in pain outcomes. There was no difference between denosumab and $\mathrm{ZA}$ in the time to decrease in worst pain severity (2.8 months) or risk (HR, $1.01 ; P=0.881$ ). Denosumab did delay the time to increase in pain interference overall (11.1 vs. 9.3 months; HR, $0.89 ; P=0.005)$, as well as pain interference with affect ( 8.4 vs. 7.5 months; HR, $0.91 ; P=0.011)$ and with activity ( 8.3 vs. 7.4 months; HR, 0.90; $P=0.009)$ compared with ZA. Overall, fewer patients who received denosumab shifted to using a 


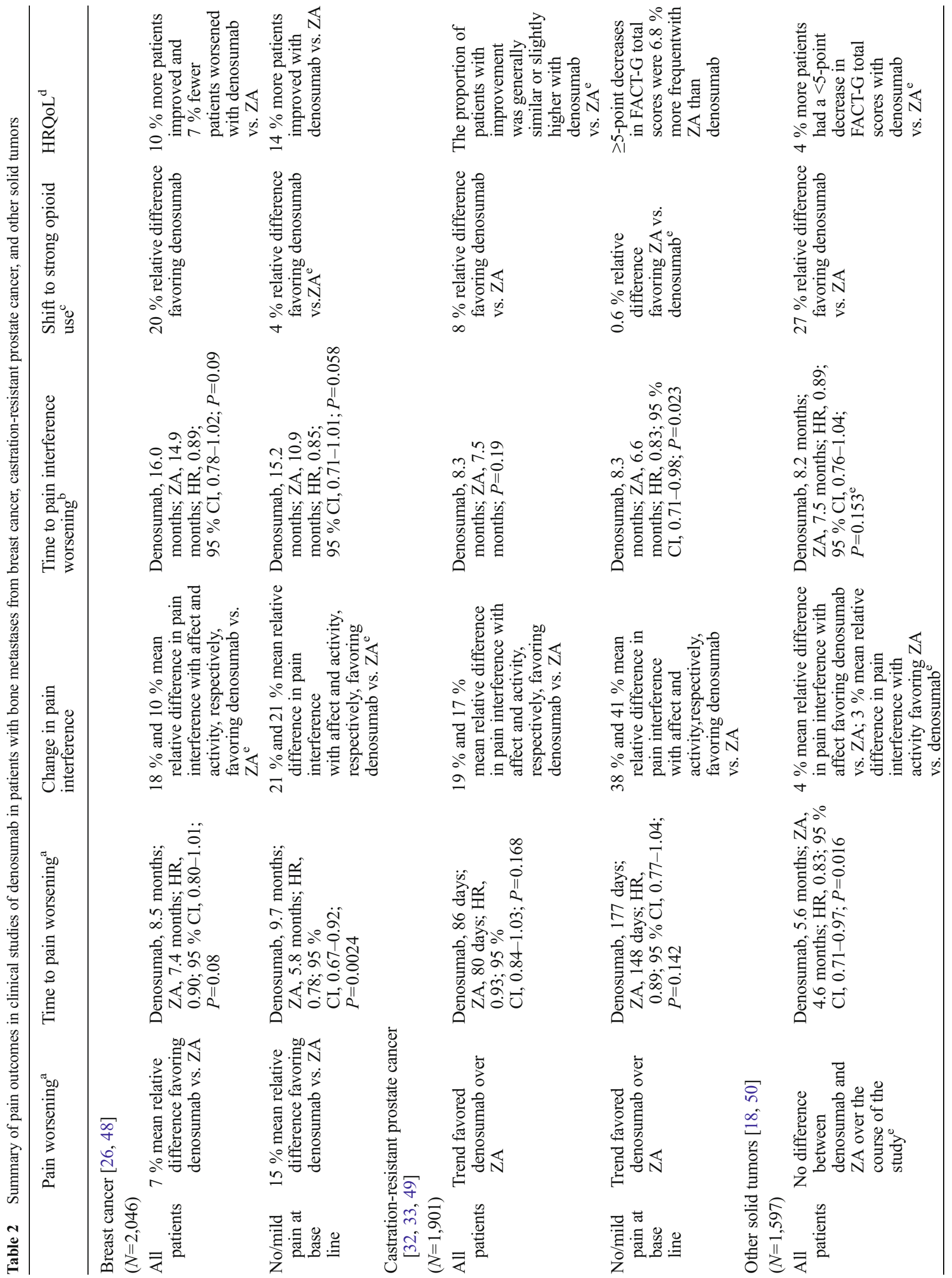


strong opioid (AQA score $\geq 3$ ) compared with ZA ( $7.7 \%$ vs. $9.1 \%$ ). Additionally, treatment with denosumab compared with ZA delayed the time to and reduced the risk of moderate or severe pain ( $>4$ points per the BPI-SF) in patients with prior SRE (5.7 vs. 3.9 months; HR, $0.81 ; P=0.019$ ) and without prior SRE (6.7 vs. 4.8 months; HR, $0.84 ; P=0.002$ ).

\section{Pain outcomes reported in clinical studies of radiotherapy in combination with bone-targeting agents}

Palliative radiotherapy, typically delivered as localized external-beam radiotherapy, is known to be effective for the management of pain associated with bone metastases [52]. Retrospective analysis of clinical trials has demonstrated improvement in pain with external-beam radiotherapy administered as a single fraction and as a longer course [53]. Longer courses of external-beam radiotherapy are associated with fewer repeat treatments to the same site, while a single fraction offers greater convenience [52].

Combining radiotherapy with bone-targeting agents may have additive effects to provide acute pain relief [54]. In addition, concomitant treatment with radiotherapy and bonetargeting agents should have a favorable toxicity profile because of the general lack of overlapping toxicities [54]. Results from a number of studies suggest that concurrent administration of bisphosphonates with external-beam radiotherapy at varying doses palliates bone pain [52]. Low-dose radiotherapy may also be a viable alternative to high-dose radiotherapy in patients receiving concomitant bisphosphonate therapy. For example, ZA $4 \mathrm{mg}$ monthly combined with low-dose radiotherapy regimens showed similar pain relief results (analgesic use and VAS pain scores) to ZA combined with high-dose radiotherapy in patients with breast cancer $(N=100)$ [55]. Another study in patients with solid tumors $(N=139$; mostly lung, prostate, and breast cancer) in which patients were randomized to receive radiotherapy (single doses, 8 vs. $6 \mathrm{~Gy}$; all patients received ZA) also supports the combined use of ZA with radiotherapy in terms of pain control, with both radiotherapy doses being equally effective for controlling pain [56]. Two small retrospective studies $(N=23$ and $N=27$ patients) in patients receiving background radiotherapy for bone metastases from renal cell carcinoma reported prolonged SRE-free survival among patients who received ZA $4 \mathrm{mg}$ monthly combined with radiotherapy relative to radiotherapy alone [57, 58]. Furthermore, in one of these retrospective studies, increased median duration of pain response was reported among patients who received ZA combined with radiotherapy compared with radiotherapy alone (25 vs. 8.7 months; $P=0.047$ ) [57]. A phase 3 study in 470 patients with metastatic prostate cancer indicated that a single dose of local radiotherapy provided pain relief (combination of WHO pain ladder score and analgesic use) similar to a single dose of 
Table 3 Changes in pain outcomes from baseline in an integrated analysis of denosumab versus zoledronic acid in patients with bone metastases from breast cancer, castration-resistant prostate cancer, and other solid tumors excluding multiple myeloma

\begin{tabular}{|c|c|c|c|c|c|c|c|}
\hline \multirow{3}{*}{ Parameter } & \multicolumn{2}{|l|}{ Incidence, $n / N(\%)$} & \multicolumn{5}{|c|}{ Median time, months } \\
\hline & \multirow[t]{2}{*}{ Denosumab } & \multirow[t]{2}{*}{ Zoledronic acid } & \multirow[t]{2}{*}{ Denosumab } & \multirow[t]{2}{*}{ Zoledronic acid } & \multirow[t]{2}{*}{ Difference } & \multicolumn{2}{|l|}{ Hazard ratio } \\
\hline & & & & & & $(95 \% \mathrm{CI})$ & $P$ value \\
\hline Decrease in worst pain severity ${ }^{a}$ & $1,326 / 2,048(65)$ & $1,320 / 2,037(65)$ & 2.8 & 2.8 & 0 & $1.01(0.93-1.09)$ & 0.881 \\
\hline \multicolumn{8}{|l|}{ Increase in pain interference ${ }^{b}$} \\
\hline Overall & $1,227 / 2,469(50)$ & $1,283 / 2,443(53)$ & 11.1 & 9.3 & 1.8 & $0.89(0.83-0.97)$ & 0.005 \\
\hline Affect & $1,318 / 2,418(55)$ & $1,361 / 2,402(57)$ & 8.4 & 7.5 & 0.9 & $0.91(0.84-0.98)$ & 0.011 \\
\hline Activity & $1,260 / 2,295(55)$ & $1,299 / 2,241(58)$ & 8.3 & 7.4 & 0.9 & $0.90(0.83-0.97)$ & 0.009 \\
\hline Patients using strong opioids ${ }^{c}$ & $(7.7)$ & $(9.1)$ & - & - & - & - & - \\
\hline \multicolumn{8}{|l|}{ Moderate to severe worst pain ${ }^{\mathrm{d}}$} \\
\hline Overall & $853 / 1,386(62)$ & $863 / 1,297(67)$ & 6.5 & 4.7 & 1.8 & $0.83(0.76-0.92)$ & 0.0002 \\
\hline Prior skeletal-related event (yes) & $265 / 429(62)$ & $247 / 366(68)$ & 5.7 & 3.9 & 1.8 & $0.81(0.68-0.97)$ & 0.019 \\
\hline Prior skeletal-related event (no) & $588 / 957(61)$ & 616/931 (66) & 6.7 & 4.8 & 1.9 & $0.84(0.74-0.94)$ & 0.002 \\
\hline
\end{tabular}

$A Q A$ Analgesic Quantification Algorithm, BPI-SF Brief Pain Inventory-Short Form, OME oral morphine equivalent

${ }^{a}$ Patients with $\mathrm{a} \geq 2$-point decrease from baseline in BPI-SF worst pain score

${ }^{\mathrm{b}}$ Patients with $\mathrm{a} \geq 2$-point increase from baseline in BPI-SF pain interference score

${ }^{\mathrm{c}}$ Mean proportion of patients with an AQA score $\geq 3$ (strong opioids from $\leq 75-600 \mathrm{mg}$ OME per day) averaged over study weeks 5-41

${ }^{\mathrm{d}}$ Patients with a $>4$-point BPI-SF worst pain score

intravenous ibandronate [59]. In two small observational studies $(N=70$ and $N=45)$, ibandronate combined with externalbeam radiotherapy in patients with bone metastases from solid tumors significantly decreased opioid use $(P<0.001$ in both studies) and improved pain scores relative to baseline [60, 61]. However, despite these preliminary results, prospective randomized studies are needed to determine whether the combination of a bone-targeting agent with radiotherapy is more effective for pain relief than radiotherapy alone.

Radionuclides with bone-seeking properties that localize to active sites of bone reaction and remodeling are also used to provide palliation to multiple sites of bone metastases from solid tumors [62]. Meta-analysis data for complete and complete/partial pain relief have shown a significant improvement for patients with solid tumors (predominantly prostate and breast cancer) who received radionuclides for pain control versus those who received placebo [52, 63]. There are limited data with bone-targeting agents in combination with radionuclides. In a small, single-arm study, combining ZA with SmEDTMP-153 was safe and did not affect bone uptake of SmEDTMP-153 in 20 patients with metastatic prostate cancer [64]. A small retrospective nonrandomized study reported that ZA combined with strontium- 89 was more effective at reducing discomfort and pain at specific sites (12 body regions) by VAS than either treatment alone in 49 patients with breast or prostate cancer and painful bone metastases [65]. In an interim analysis of 809 patients from a phase 3 randomized placebocontrolled study in patients with prostate cancer and bone metastases $(41 \%$ of patients were using concurrent bisphosphonates), the times to initial opioid use and to external-beam radiation therapy use were lower in the radium-223 group than in the placebo group [66]. In addition, there was a survival benefit in the radium-223 group [67]. Moreover, patients receiving concurrent bisphosphonate treatment at study entry tended to have a longer time to first SRE than patients not receiving bisphosphonates [68].

\section{Discussion}

Given that pain associated with bone metastases is often undertreated and that analgesics reduce the symptoms of bone pain but do not address the underlying cause, bone-targeting agents play an important role in delaying pain progression and reduce analgesic use by reducing the risk of potentially painful SREs such as fractures and spinal cord compression. Intravenous bisphosphonates such as ZA were previously the standard treatment option for bone metastases in patients with metastatic cancer, although, more recently, subcutaneous denosumab has become an alternative and more efficacious option [12, 69-72]. Patients receiving potent antiresorptive agents, including denosumab, should be properly supplemented with calcium and vitamin $\mathrm{D}$ to minimize the occurrence of hypocalcemia. Both bisphosphonates and denosumab have been shown to reduce SREs, thereby improving pain outcomes, and reduce the need for strong opioids in patients with bone metastases from advanced solid tumors such as breast or prostate cancer $[19,26,32,33,43,45-47,50,51,73]$. In an 
integrated analysis of randomized double-blind studies of denosumab versus $\mathrm{ZA}$ in patients with bone metastases from advanced solid tumors reported here and previously [51], treatment with denosumab was associated with an overall reduced risk of increased pain severity and a delayed shift to the use of strong opioids compared with ZA [51]. Among patients with no or mild pain at baseline, denosumab delayed development of worst pain, reduced the risk of increased pain severity, and delayed time to increased pain interference per the BPI-SF versus ZA. In this study, we found that the delay in time to progression to and the reduced risk of moderate to severe pain by denosumab versus ZA occurred independently of whether patients had prior SREs.

Initial data from small studies suggest that combining the bisphosphonate ZA with either localized external-beam radiotherapy [57] or radionuclides (strontium-89) [65] provides a greater reduction in pain and discomfort relative to radiotherapy alone in patients with bone metastases. A recent study on radium-223 used in combination with intravenous bisphosphonates in metastatic prostate cancer showed improvements in a number of pain measures per the BPI-SF [67]. Earlier initiation of analgesics and bone-targeting agents may prove beneficial in reducing rates of radiotherapy retreatment [74].

There are several important considerations when assessing bone-targeting agents such as denosumab for the prevention of SREs in patients with bone metastases from advanced solid tumors. Because bone metastases may remain asymptomatic (i.e., without pain) for extended periods of time before damage to bone is detected, early treatment is essential. An exploratory analysis of two randomized trials of $\mathrm{ZA}$ in patients with bone metastases from breast, lung, or solid tumors showed that those who had not yet developed bone pain at baseline had greater benefit from ZA in delaying time to SREs [75]. Furthermore, when interpreting the results of trials assessing bone-targeting agents in patients with bone metastases, it is important to consider the consequences of whether differing endpoints (i.e., symptomatic vs. skeletal survey) have been used. Because SREs such as pathologic fractures may remain asymptomatic for extended time periods, the events may go unreported by a symptomatic scale, thereby affecting trial duration and the ability to capture treatment differentiation in pain. Most recent studies of bone-targeting agents have assessed the effect of treatment on the risk or timing of $\geq 2$-point increases in pain per the BPI-SF, whereas older studies have assessed differences between groups based on the VAS. Regarding pain and SREs, exploratory results from phase 3 studies of the anticancer agents enzalutamide and abiraterone in patients with bone metastases and prostate cancer demonstrated the benefit of adding bisphosphonates to the therapeutic agent [76-78]. Additionally, differences in patient groups, such as the extent of metastasis at baseline, elevated bone turnover markers, and prior SREs, may affect pain and the response to therapy.

Reducing the burden of pain associated with bone metastases is an important therapeutic goal in patients with advanced cancer. There are a number of viable measures (e.g., BPI-SF and AQA) available to assist clinicians with the initial assessment of pain and to monitor the effect of treatment over time, and therefore, proper pain assessment in these patients should not be an obstacle to optimal pain management. Bonetargeting agents such as bisphosphonates and denosumab have been shown to delay the progression of pain associated with bone metastases in patients with advanced cancer. There are also data to suggest that earlier use of these agents in this setting (before patients develop bone pain) may improve pain outcomes, although the optimum timing and duration of bonetargeting treatment may warrant further investigation [75]. Nonetheless, the data presented in this review underscore the importance of using validated pain assessments to optimize treatment and reduce the burden of pain associated with bone metastases in advanced cancer.

Acknowledgments The authors would like to acknowledge Benjamin Scott, PhD, and Rick Davis, MS, RPh (Complete Healthcare Communications, Inc.), whose work was funded by Amgen Inc., for assistance in preparing this manuscript.

Conflicts of interest The sponsors contributed to the collection, analysis, and interpretation of the integrated analysis of pain outcomes with denosumab versus zoledronic acid in patients with bone metastases from advanced cancers. All of the authors were involved in writing the manuscript and the decision to submit the manuscript for publication, and will allow the editorial staff of Supportive Care in Cancer to review the data if necessary. DLP has been a consultant and speaker for Amgen Inc. CSC has been a consultant for Amgen Inc. RvM has served on advisory boards for Amgen Inc., Bristol-Myers Squibb, GlaxoSmithKline, MSD, MerckSerono, Novartis, and Roche, and has received research grants from Amgen Inc., Merck-Serono, and Roche. LF has been a consultant and speaker for Amgen Inc. RW, KÖ, and YQ are employees of and own stock in Amgen Inc.

\section{References}

1. Coleman RE (2006) Clinical features of metastatic bone disease and risk of skeletal morbidity. Clin Cancer Res 12:6243s-6249s

2. Harris K, Chow E, Zhang L, Velikova G, Bezjak A, Wu J, Barton M, Sezer O, Eek R, Shafiq J, Yee A, Clemons M, Brundage M, Hoskin P, van der Linden Y, Johnson CD, Bottomley A, Group EQoL (2009) Patients' and health care professionals' evaluation of health-related quality of life issues in bone metastases. Eur J Cancer 45:2510-2518

3. Langer C, Hirsh V (2010) Skeletal morbidity in lung cancer patients with bone metastases: demonstrating the need for early diagnosis and treatment with bisphosphonates. Lung Cancer 67:4-11

4. Coleman RE (1997) Skeletal complications of malignancy. Cancer 80:1588-1594

5. Coleman RE (2004) Bisphosphonates: clinical experience. Oncologist 9:14-27 
6. Weinfurt KP, Li Y, Castel LD, Saad F, Timbie JW, Glendenning GA, Schulman KA (2005) The significance of skeletal-related events for the health-related quality of life of patients with metastatic prostate cancer. Ann Oncol 16:579-584

7. Fisch MJ, Lee JW, Weiss M, Wagner LI, Chang VT, Cella D, Manola JB, Minasian LM, McCaskill-Stevens W, Mendoza TR, Cleeland CS (2012) Prospective, observational study of pain and analgesic prescribing in medical oncology outpatients with breast, colorectal, lung, or prostate cancer. J Clin Oncol 30:1980-1988

8. Deandrea S, Montanari M, Moja L, Apolone G (2008) Prevalence of undertreatment in cancer pain. A review of published literature. Ann Oncol 19:1985-1991

9. Apolone G, Corli O, Caraceni A, Negri E, Deandrea S, Montanari M, Greco MT, Cancer Pain Outcome Research Study Group I (2009) Pattern and quality of care of cancer pain management. Results from the Cancer Pain Outcome Research study group. Br J Cancer 100: 1566-1574

10. World Health Organization (1996) Cancer pain relief. With a guide to opioid availability, 2nd edition. Geneva, Switzerland

11. Ripamonti CI, Santini D, Maranzano E, Berti M, Roila F, Group EGW (2012) Management of cancer pain: ESMO clinical practice guidelines. Ann Oncol 23:vii139-154

12. National Comprehensive Cancer Network (2013) NCCN clinical practice guidelines in oncology (NCCN Guidelines $\left.{ }^{\circledR}\right)$. Non-small cell lung cancer. Version 2.2013. Available at: http://www.ncen.org/ professionals/physician_gls/PDF/nscl.pdf. Accessed 19 Sept 2013

13. Caraceni A, Hanks G, Kaasa S, Bennett MI, Brunelli C, Cherny N, Dale O, De Conno F, Fallon M, Hanna M, Haugen DF, Juhl G, King S, Klepstad P, Laugsand EA, Maltoni M, Mercadante S, Nabal M, Pigni A, Radbruch L, Reid C, Sjogren P, Stone PC, Tassinari D, Zeppetella G, European Palliative Care Research Collaborative (EPCRC), European Association for Palliative Care (EAPC) (2012) Use of opioid analgesics in the treatment of cancer pain: evidence-based recommendations from the EAPC. Lancet Oncol 13:e58-68

14. National Comprehensive Cancer Network (2014) NCCN clinical practice guidelines in oncology $\left(\mathrm{NCCN}\right.$ Guidelines $\left.{ }^{\circledR}\right)$. Adult cancer pain version 2.2014. Available at: http://www.nccn.org/professionals/ physician_gls/pdf/pain.pdf. Accessed 19 June 2014

15. Fizazi K, Carducci M, Smith M, Damiao R, Brown J, Karsh L, Milecki P, Shore N, Rader M, Wang H, Jiang Q, Tadros S, Dansey R, Goessl C (2011) Denosumab versus zoledronic acid for treatment of bone metastases in men with castration-resistant prostate cancer: a randomised, double-blind study. Lancet 377:813-822

16. Stopeck AT, Lipton A, Body JJ, Steger GG, Tonkin K, de Boer RH, Lichinitser M, Fujiwara Y, Yardley DA, Viniegra M, Fan M, Jiang Q, Dansey R, Jun S, Braun A (2010) Denosumab compared with zoledronic acid for the treatment of bone metastases in patients with advanced breast cancer: a randomized, double-blind study. J Clin Oncol 28:5132-5139

17. Henry DH, Costa L, Goldwasser F, Hirsh V, Hungria V, Prausova J, Scagliotti GV, Sleeboom H, Spencer A, Vadhan-Raj S, von Moos R, Willenbacher W, Woll PJ, Wang J, Jiang Q, Jun S, Dansey R, Yeh H (2011) Randomized, double-blind study of denosumab versus zoledronic acid in the treatment of bone metastases in patients with advanced cancer (excluding breast and prostate cancer) or multiple myeloma. J Clin Oncol 29:1125-1132

18. Vadhan-Raj S, von Moos R, Fallowfield LJ, Patrick DL, Goldwasser F, Cleeland CS, Henry DH, Novello S, Hungria V, Qian Y, Feng A, Yeh H, Chung K (2012) Clinical benefit in patients with metastatic bone disease: results of a phase 3 study of denosumab versus zoledronic acid. Ann Oncol 23:3045-3051

19. Saad F, Gleason DM, Murray R, Tchekmedyian S, Venner P, Lacombe L, Chin JL, Vinholes JJ, Goas JA, Chen B (2002) A randomized, placebo-controlled trial of zoledronic acid in patients with hormone-refractory metastatic prostate carcinoma. J Natl Cancer Inst 94:1458-1468

20. Saad F, Chen YM, Gleason DM, Chin J (2007) Continuing benefit of zoledronic acid in preventing skeletal complications in patients with bone metastases. Clin Genitourin Cancer 5:390-396

21. Rosen LS, Gordon DH, Dugan W Jr, Major P, Eisenberg PD, Provencher L, Kaminski M, Simeone J, Seaman J, Chen BL, Coleman RE (2004) Zoledronic acid is superior to pamidronate for the treatment of bone metastases in breast carcinoma patients with at least one osteolytic lesion. Cancer 100:36-43

22. Kohno N, Aogi K, Minami H, Nakamura S, Asaga T, Iino Y, Watanabe T, Goessl C, Ohashi Y, Takashima S (2005) Zoledronic acid significantly reduces skeletal complications compared with placebo in Japanese women with bone metastases from breast cancer: a randomized, placebo-controlled trial. J Clin Oncol 23:3314-3321

23. von Moos R, Strasser F, Gillessen S, Zaugg K (2008) Metastatic bone pain: treatment options with an emphasis on bisphosphonates. Support Care Cancer 16:1105-1115

24. Fallowfield L, von Moos R, Costa L, Stopeck A, Clemons M, Clarke N, Braun A, Chung K (2012) Weighing bone-targeted treatment options for patients with solid tumours and skeletal complications from metastatic disease. Eur Oncol Haematol 8:148-155

25. Dworkin RH, Turk DC, Wyrwich KW, Beaton D, Cleeland CS, Farrar JT, Haythornthwaite JA, Jensen MP, Kerns RD, Ader DN, Brandenburg N, Burke LB, Cella D, Chandler J, Cowan P, Dimitrova R, Dionne R, Hertz S, Jadad AR, Katz NP, Kehlet H, Kramer LD, Manning DC, McCormick C, McDermott MP, McQuay HJ, Patel S, Porter L, Quessy S, Rappaport BA, Rauschkolb C, Revicki DA, Rothman M, Schmader KE, Stacey BR, Stauffer JW, von Stein T, White RE, Witter J, Zavisic S (2008) Interpreting the clinical importance of treatment outcomes in chronic pain clinical trials: IMMPACT recommendations. J Pain 9:105-121

26. Cleeland CS, Body JJ, Stopeck A, von Moos R, Fallowfield L, Mathias SD, Patrick DL, Clemons M, Tonkin K, Masuda N, Lipton A, de Boer R, Salvagni S, Oliveira CT, Qian Y, Jiang Q, Dansey R, Braun A, Chung K (2013) Pain outcomes in patients with advanced breast cancer and bone metastases: results from a randomized, double-blind study of denosumab and zoledronic acid. Cancer 119: 832-838

27. Chung KC, Barlev A, Braun AH, Qian Y, Zagari M (2014) Assessing analgesic use in patients with advanced cancer: development of a new scale - the Analgesic Quantification Algorithm. Pain Med 15:225232

28. Mathias SD, Crosby RD, Qian Y, Jiang Q, Dansey R, Chung K (2011) Estimating minimally important differences for the worst pain rating of the brief pain inventory-short form. J Support Oncol 9:72-78

29. Basch E, Autio K, Ryan CJ, Mulders P, Shore N, Kheoh T, Fizazi K, Logothetis CJ, Rathkopf D, Smith MR, Mainwaring PN, Hao Y, Griffin T, Li S, Meyers ML, Molina A, Cleeland C (2013) Abiraterone acetate plus prednisone versus prednisone alone in chemotherapy-naive men with metastatic castration-resistant prostate cancer: patient-reported outcome results of a randomised phase 3 trial. Lancet Oncol 14:1193-1199

30. Cleeland CS (2006) The measurement of pain from metastatic bone disease: capturing the patient's experience. Clin Cancer Res 12: 6236s-6242s

31. Matza LS, Fallowfield LJ, Chung KC, Currie BM, Van Brunt K, Patrick DL (2012) Patient-reported outcome instruments used to assess pain and functioning in studies of bisphosphonate treatment for bone metastases. Support Care Cancer 20:657-677

32. Brown JE, Cleeland CS, Fallowfield LJ, Patrick DL, Fizazi K, Smith MR, Maroto JP, Michel MS, Feng A, Goessl C, Chung K (2011) Pain outcomes in patients with bone metastases from castrate-resistant prostate cancer: results from a phase 3 trial of denosumab vs. zoledronic acid [abstract \#1091]. Presented at: 26th Annual EAU Congress, Vienna, Austria 
33. Patrick DL, Cleeland C, Fallowfield L, Smith MR, Trachtenberg J, Chilingirov P, Michel MS, Oudard S, Feng A, Chung K (2011) Effects of denosumab and zoledronic acid on pain interference with daily functioning in patients with castrate-resistant prostate cancer [abstract \#711]. J Urol 185:e286

34. Hortobagyi GN, Theriault RL, Porter L, Blayney D, Lipton A, Sinoff C, Wheeler H, Simeone JF, Seaman J, Knight RD (1996) Efficacy of pamidronate in reducing skeletal complications in patients with breast cancer and lytic bone metastases. Protocol 19 Aredia Breast Cancer study group. N Engl J Med 335:1785-1791

35. Hortobagyi GN, Theriault RL, Lipton A, Porter L, Blayney D, Sinoff C, Wheeler H, Simeone JF, Seaman JJ, Knight RD, Heffernan M, Mellars K, Reitsma DJ (1998) Long-term prevention of skeletal complications of metastatic breast cancer with pamidronate. Protocol 19 Aredia Breast Cancer study group. J Clin Oncol 16: 2038-2044

36. Theriault RL, Lipton A, Hortobagyi GN, Leff R, Gluck S, Stewart JF, Costello S, Kennedy I, Simeone J, Seaman JJ, Knight RD, Mellars K, Heffernan M, Reitsma DJ (1999) Pamidronate reduces skeletal morbidity in women with advanced breast cancer and lytic bone lesions: a randomized, placebo-controlled trial. Protocol 18 Aredia Breast Cancer study group. J Clin Oncol 17:846-854

37. Body JJ, Diel IJ, Lichinitser MR, Kreuser ED, Dornoff W, Gorbunova VA, Budde M, Bergstrom B, Group MFS (2003) Intravenous ibandronate reduces the incidence of skeletal complications in patients with breast cancer and bone metastases. Ann Oncol 14:1399-1405

38. Diel IJ, Body JJ, Lichinitser MR, Kreuser ED, Dornoff W, Gorbunova VA, Budde M, Bergström B, MF 4265 Study Group (2004) Improved quality of life after long-term treatment with the bisphosphonate ibandronate in patients with metastatic bone disease due to breast cancer. Eur J Cancer 40:1704-1712

39. Body JJ, Diel IJ, Bell R, Pecherstorfer M, Lichinitser MR, Lazarev AF, Tripathy D, Bergström B (2004) Oral ibandronate improves bone pain and preserves quality of life in patients with skeletal metastases due to breast cancer. Pain 111:306-312

40. Altundag K, Dizdar O, Ozsaran Z, Ozkok S, Saip P, Eralp Y, Komurcu S, Kuzhan O, Ozguroglu M, Karahoca M (2012) Phase II study of loading-dose ibandronate treatment in patients with breast cancer and bone metastases suffering from moderate to severe pain. Onkologie 35:254-258

41. Ernst DS, Tannock IF, Winquist EW, Venner PM, Reyno L, Moore MJ, Chi K, Ding K, Elliott C, Parulekar W (2003) Randomized, double-blind, controlled trial of mitoxantrone/prednisone and clodronate versus mitoxantrone/prednisone and placebo in patients with hormone-refractory prostate cancer and pain. J Clin Oncol 21: 3335-3342

42. Rosen LS, Gordon D, Tchekmedyian NS, Yanagihara R, Hirsh V, Krzakowski M, Pawlicki M, De Souza P, Zheng M, Urbanowitz G, Reitsma D, Seaman J (2004) Long-term efficacy and safety of zoledronic acid in the treatment of skeletal metastases in patients with nonsmall cell lung carcinoma and other solid tumors: a randomized, phase III, double-blind, placebo-controlled trial. Cancer 100: 2613-2621

43. Weinfurt KP, Anstrom KJ, Castel LD, Schulman KA, Saad F (2006) Effect of zoledronic acid on pain associated with bone metastasis in patients with prostate cancer. Ann Oncol 17:986-989

44. Wardley A, Davidson N, Barrett-Lee P, Hong A, Mansi J, Dodwell D, Murphy R, Mason T, Cameron D (2005) Zoledronic acid significantly improves pain scores and quality of life in breast cancer patients with bone metastases: a randomised, crossover study of community vs hospital bisphosphonate administration. Br J Cancer 92:18691876

45. Rosen LS, Gordon D, Kaminski M, Howell A, Belch A, Mackey J, Apffelstaedt J, Hussein M, Coleman RE, Reitsma DJ, Seaman JJ, Chen BL, Ambros Y (2001) Zoledronic acid versus pamidronate in the treatment of skeletal metastases in patients with breast cancer or osteolytic lesions of multiple myeloma: a phase III, double-blind, comparative trial. Cancer J 7:377-387

46. Cartenì G, Bordonaro R, Giotta F, Lorusso V, Scalone S, Vinaccia V, Rondena R, Amadori D (2006) Efficacy and safety of zoledronic acid in patients with breast cancer metastatic to bone: a multicenter clinical trial. Oncologist 11:841-848

47. Kretzschmar A, Wiegel T, Al-Batran SE, Hinrichs H, Kindler M, Steck T, Illiger H, Heinemann V, Schmidt K, Haus U, Kirner A, Ehninger G (2007) Rapid and sustained influence of intravenous zoledronic acid on course of pain and analgesics consumption in patients with cancer with bone metastases: a multicenter open-label study over 1 year. Support Cancer Ther 4:203-210

48. Martin M, Bell R, Bourgeois H, Brufsky A, Diel I, Eniu A, Fallowfield L, Fujiwara Y, Jassem J, Paterson AH, Ritchie D, Steger GG, Stopeck A, Vogel C, Fan M, Jiang Q, Chung K, Dansey R, Braun A (2012) Bone-related complications and quality of life in advanced breast cancer: results from a randomized phase III trial of denosumab versus zoledronic acid. Clin Cancer Res 18:48414849

49. Patrick D, Cleeland C, Fallowfield L, Smith M, Klotz L, Oudard S, Marx G, Wei R, Öhrling K, Qian Y (2014) Denosumab or zoledronic acid (ZA) therapy on pain interference and cancer-specific quality of life $(\mathrm{CSQoL})$ in patients with castrate-resistant prostate cancer (CRPC) and bone metastases (BM) [abstract accepted]. Presented at: 2014 Genitourinary Cancers Symposium; January 30-February 1, 2014; San Francisco, CA

50. Henry D, Vadhan-Raj S, Hirsh V, von Moos R, Hungria V, Costa L, Woll PJ, Scagliotti G, Smith G, Feng A, Jun S, Dansey R, Yeh H (2014) Delaying skeletal-related events in a randomized phase 3 study of denosumab versus zoledronic acid in patients with advanced cancer: an analysis of data from patients with solid tumors. Support Care Cancer 22:679-687

51. von Moos R, Body JJ, Egerdie B, Stopeck A, Brown JE, Damyanov D, Fallowfield LJ, Marx G, Cleeland CS, Patrick DL, Palazzo FG, Qian Y, Braun A, Chung K (2013) Pain and health-related quality of life in patients with advanced solid tumours and bone metastases: integrated results from three randomized, double-blind studies of denosumab and zoledronic acid. Support Care Cancer 21:3497-3507

52. Lutz S, Berk L, Chang E, Chow E, Hahn C, Hoskin P, Howell D, Konski A, Kachnic L, Lo S, Sahgal A, Silverman L, von Gunten C, Mendel E, Vassil A, Bruner DW, Hartsell W, American Society for Radiation Oncology (ASTRO) (2011) Palliative radiotherapy for bone metastases: an ASTRO evidence-based guideline. Int J Radiat Oncol Biol Phys 79:965-976

53. Chow E, Harris K, Fan G, Tsao M, Sze WM (2007) Palliative radiotherapy trials for bone metastases: a systematic review. J Clin Oncol 25:1423-1436

54. Hoskin P (2003) Bisphosphonates and radiation therapy for palliation of metastatic bone disease. Cancer Treat Rev 29: 321-327

55. Atahan L, Yildiz F, Cengiz M, Kaplan B, Ozkan M, Yazici G, Gündoğ M, Haydaroğlu A, Korcum AF, Sengöz M, Dinçer M, Akmansu M, Engin K, Hayran M (2010) Zoledronic acid concurrent with either high- or reduced-dose palliative radiotherapy in the management of the breast cancer patients with bone metastases: a phase IV randomized clinical study. Support Care Cancer 18:691-698

56. Mañas A, Casas F, Ciria JP, López C, Sáez J, Palacios A, de las Heras M, Porto C, Sánchez E, Martín C, Esco R, Veiras C, Martínez JC, Márquez M, Ramos A, Calvo F, Fuertes J, Andreu FJ, Contreras J, Pérez L, Romero J, Vayreda J, Victoria C (2008) Randomised study of single dose ( 8 Gy vs. 6 Gy) of analgesic radiotherapy plus zoledronic acid in patients with bone metastases. Clin Transl Oncol 10:281-287

57. Takeda N, Isu K, Hiraga H, Shinohara N, Minami A, Kamata H (2012) Zoledronic acid enhances the effect of radiotherapy for bone 
metastases from renal cell carcinomas: more than a 24-month median follow-up. J Orthop Sci 17:770-774

58. Kijima T, Fujii Y, Suyama T, Okubo Y, Yamamoto S, Masuda H, Yonese J, Fukui I (2009) Radiotherapy to bone metastases from renal cell carcinoma with or without zoledronate. BJU Int 103:620-624

59. Hoskin P, Sundar S, Reczko K (2011) A multicenter randomized trial of ibandronate compared to single dose radiotherapy for localized metastatic bone pain in prostate cancer (RIB) [abstract 7LBA]. Eur J Cancer 47:6

60. Vassiliou V, Kalogeropoulou C, Christopoulos C, Solomou E, Leotsinides M, Kardamakis D (2007) Combination ibandronate and radiotherapy for the treatment of bone metastases: clinical evaluation and radiologic assessment. Int J Rad Oncol Biol Phys 67:264-272

61. Vassiliou V, Kalogeropoulou C, Giannopoulou E, Leotsinidis M, Tsota I, Kardamakis D (2007) A novel study investigating the therapeutic outcome of patients with lytic, mixed and sclerotic bone metastases treated with combined radiotherapy and ibandronate. Clin Exp Metastasis 24:169-178

62. Tomblyn M (2012) The role of bone-seeking radionuclides in the palliative treatment of patients with painful osteoblastic skeletal metastases. Cancer Control 19:137-144

63. Roque IFM, Martinez-Zapata MJ, Scott-Brown M, Alonso-Coello P (2011) Radioisotopes for metastatic bone pain. Cochrane Database Syst Rev:CD003347

64. Lam MG, Dahmane A, Stevens WH, van Rijk PP, de Klerk JM, Zonnenberg BA (2008) Combined use of zoledronic acid and $153 \mathrm{Sm}$-EDTMP in hormone-refractory prostate cancer patients with bone metastases. Eur J Nucl Med Mol Imaging 35:756-765

65. Storto G, Klain M, Paone G, Liuzzi R, Molino L, Marinelli A, Soricelli A, Pace L, Salvatore M (2006) Combined therapy of Sr-89 and zoledronic acid in patients with painful bone metastases. Bone 39:35-41

66. Nilsson S, Sartor AO, Bruland OS, Fang F, Aksnes A-K, Parker C (2013) Pain analyses from the phase III randomized ALSYMPCA study with radium-223 dichloride (Ra-223) in castration-resistant prostate cancer (CRPC) patients with bone metastases. J Clin Oncol 31:5038

67. Parker C, Nilsson S, Heinrich D, Helle SI, O’Sullivan JM, Fossa SD, Chodacki A, Wiechno P, Logue J, Seke M, Widmark A, Johannessen DC, Hoskin P, Bottomley D, James ND, Solberg A, Syndikus I, Kliment J, Wedel S, Boehmer S, Dall'Oglio M, Franzen L, Coleman R, Vogelzang NJ, O'Bryan-Tear CG, Staudacher K, Garcia-Vargas J, Shan M, Bruland OS, Sartor O, ALSYMPCA Investigators (2013) Alpha emitter radium-223 and survival in metastatic prostate cancer. N Engl J Med 369:213-223

68. Coleman R, Fossa S, Chodacki A, Wedel S, Bruland O, Staudacher K, Garcia-Vargas J, Sartor O (2013) Time to first skeletal-related event (SRE) with radium-223 dichloride (Ra-223) in patients with castration-resistant prostate cancer (CRPC) and bone metastases: ALSYMPCA trial stratification factors analysis [abstract \#2876]. Presented at: European Cancer Congress; Sept 27-Oct 1, 2013; Amsterdam, Netherlands
69. National Comprehensive Cancer Network (2013) NCCN clinical practice guidelines in oncology ( $\mathrm{NCCN}$ Guidelines ${ }^{\mathrm{TM}}$ ). Prostate cancer. Version 4.2013. Available at: http://www.ncen.org/professionals/ physician_gls/PDF/prostate.pdf. Accessed 19 Sept 2013

70. National Comprehensive Cancer Network (2013) NCCN clinical practice guidelines in oncology ( $\mathrm{NCCN}$ Guidelines ${ }^{\mathrm{TM}}$ ). Breast cancer. Version 3.2013. Available at: http://www.nccn.org/professionals/ physician gls/PDF/breast.pdf. Accessed 19 Sept 2013

71. National Comprehensive Cancer Network (2013) NCCN clinical practice guidelines in oncology (NCCN Guidelines ${ }^{\mathrm{TM}}$ ). Thyroid carcinoma. Version 2.2013. Available at: http://www. nccn.org/professionals/physician_gls/pdf/thyroid.pdf. Accessed 19 Sept 2013

72. National Comprehensive Cancer Network (2013) NCCN clinical practice guidelines in oncology ( $\mathrm{NCCN}$ Guidelines ${ }^{\mathrm{TM}}$ ). Kidney cancer. Version 1.2013. Available at: http://www. nccn.org/professionals/physician_gls/pdf/kidney.pdf. Accessed 19 Sept 2013

73. Patrick D, Cleeland C, Fallowfield L, Smith M, Trachtenberg J, Oudard S, Feng A, Goessl C, Chung K (2012) Pain interference with daily functioning in patients with castrate-resistant prostate cancer: a comparison of denosumab and zoledronic acid [abstract \#943]. J Urol 187:e384

74. Huisman M, van den Bosch MA, Wijlemans JW, van Vulpen M, van der Linden YM, Verkooijen HM (2012) Effectiveness of reirradiation for painful bone metastases: a systematic review and meta-analysis. Int J Rad Oncol Biol Phys 84:8-14

75. Costa L, Lipton A, Hadji P, Chen YM, Kosmidis P (2013) Treatment of bone metastases before the onset of pain. Int J Clin Oncol 18:531-538

76. Logothetis C, De Bono JS, Molina A, Basch EM, Fizazi K, North SA, Chi K, Jones RJ, Goodman OB, Mainwaring P, Sternberg CN, Gagnon DD, Dhawan R, Hao Y, Liu CS, Kheoh T, Scher HI, Haqq CM (2011) Effect of abiraterone acetate (AA) on pain control and skeletal-related events (SRE) in patients (pts) with metastatic castration-resistant prostate cancer (mCRPC) post docetaxel (D): results from the COU-AA-301 phase III study. J Clin Oncol 20: 4520

77. Logothetis CJ, Basch E, Molina A, Fizazi K, North SA, Chi KN, Jones RJ, Goodman OB, Mainwaring PN, Sternberg CN, Efstathiou E, Gagnon DD, Rothman M, Hao Y, Liu CS, Kheoh TS, Haqq CM, Scher HI, de Bono JS (2012) Effect of abiraterone acetate and prednisone compared with placebo and prednisone on pain control and skeletal-related events in patients with metastatic castration-resistant prostate cancer: exploratory analysis of data from the COU-AA-301 randomised trial. Lancet Oncol 13:1210 1217

78. Scher HI, Fizazi K, Saad F, Taplin ME, Sternberg CN, Miller K, de Wit R, Mulders P, Chi KN, Shore ND, Armstrong AJ, Flaig TW, Fléchon A, Mainwaring P, Fleming M, Hainsworth JD, Hirmand M, Selby B, Seely L, de Bono JS, Investigators A (2012) Increased survival with enzalutamide in prostate cancer after chemotherapy. N Engl J Med 367:1187-1197 